\title{
Urban tourism and climate change: Risk perceptions of business tourism stakeholders in Johannesburg, South Africa
}

\begin{abstract}
The nexus of climate change and cities is acknowledged as of growing importance for inter-disciplinary research. In this article the focus is upon the perceptions of climate change and responses by tourism stakeholders in Johannesburg, South Africa's leading city and major tourism destination. Using semi-structured qualitative interviews with 30 tourism stakeholders an analysis is undertaken of the risk perceptions of climate change. Overall the results suggest a major disconnect between the climate change threats as openly recognised by Johannesburg city authorities and of the risk perceptions as revealed by local tourism stakeholders. The predominant view articulated by tourism industry stakeholders is that climate change responses and associated sustainability initiatives are something of a 'nice to have' rather than a necessity given current the current state of awareness and of climate change risk perceptions by businesses.
\end{abstract}

Keywords: climate change, urban tourism, risk perceptions, tourism businesses, Johannesburg, South Africa

\section{Introduction}

Climate change is recognised as a fundamental challenge to cities in coming decades as it potentially will affect large groups of businesses and residents in what some style as "this century of urbanization" (Reckien et al., 2017: 159). Carmin et al. (2012: 18) observe that throughout the world cities "are experiencing new weather and climate patterns that are being attributed to global climate change". Accordingly, with more than half the world's population now living in cities there is "a growing resonance in considering city-scale issues in order to progress climate policy discussions" (Hunt \& Watkiss, 2007: 9). In particular, it is acknowledged urban areas will need to mitigate and adapt to the impacts of global warming and cope with increased incidence of heat waves, water shortages, storm surges and natural disasters which, in turn, can impact urban infrastructure, stress services and the habitability of the built environment (Satterthwaite et al., 2007; Jones, 2017). In one recent global overview on climate change impacts in cities it was concluded significant ramifications exist most especially for those cities in coastal or riverine locations, resource-dependent regions or locations "at risk from extreme weather events, especially those undergoing rapid urbanisation" (Hunt \& Watkiss, 2007: 3). Nevertheless, whilst climate change is set to impact cities in all parts of the world "scientific projections suggest that urban areas in the global south are likely to experience some of the most immediate and severe impacts" (Carmin et al., 2012: 18). Arguably, as the populations of many cities in the global South are expanding faster than physical infrastructure, it is considered that their exposure to climate change impacts is far greater than those in developed countries (Hunt \& Watkiss, 2007).

In extant global surveys on climate change impacts on cities one of the most important effects is identified as that upon tourism (Hunt \& Watkiss, 2007). Against the backdrop of global 
economic restructuring, deindustrialization and associated employment losses in cities, during the 1980s tourism promotion emerged as an increasingly significant vehicle for urban economic regeneration and place-based development (Law, 1992, 1993). Across Europe and North America many cities had few options for economic development other than tourism and began to establish an "infrastructure of play" with new sports stadia, festival places, cultural events, museums and entertainment centres to enhance their competitiveness as tourism destinations (Cudny, 2011; Kadar, 2013; Judd, 2015; Pasquinelli, 2015). Other cities turned to support business tourism through the construction of new conference and exhibition centres. Arguably, with the rising significance of tourism for urban development the effects of climate change on tourism must be regarded "as a potentially important impact area" in research concerning climate change and cities (Hunt \& Watkiss, 2007: 28). Indeed, the consequences of climate change for present-day and future urban tourism cannot be overlooked especially by tourism scholars. Only recently in Europe there has been an awakening to the need for research to explore future shifts in patterns of urban tourism in relation to global climate change (Eliasson \& Thorsson, 2018). This said, Arit (2009: 12) observes urban tourism and climate change "is almost never a topic in publications and during conferences on climate change and tourism". Further, across several international reviews of research around tourism and climate change it is recorded that minimal if any acknowledgement is given to urban issues (see eg. Hall, 2008; Becken, 2013; Pang et al., 2013; Kaján \& Saarinen, 2013; Fang et al., 2018; Hall, 2018).

The aim in this article is to respond to the observation made that the nexus of climate change and urban tourism represents "a new and fruitful area of research that can and should be opened" (Arit, 2009: 12). South Africa is an appropriate setting for such research investigations for several reasons. First, in the global context, the sub-region of southern Africa is viewed as one of the most vulnerable to the impacts of climate change. In South Africa climate change impacts are considered as "not a narrow environmental problem but a fundamental development challenge" (Urquhart et al., 2014: 69). An enhanced understanding of the impacts of climate change and of adaptations to climate change is essential for informing strategic interventions for both tourism and local economic development futures in South Africa (Golder Associates, 2012; Rogerson, 2014, 2016; Pandy, 2017; Pandy \& Rogerson, 2018). Second, as a consequence of the threats posed by climate change to many social and economic achievements made since democratic transition in 1994, national government committed "to communicate and implement an effective nationally determined climate change response, including mitigation and adaptation actions" (Department of Environmental Affairs, 2018: 7). For the tourism sector specific adaptation and mitigation plans are currently in preparation (Department of Tourism, 2012). Third, whilst as a tourism destination South Africa usually is associated most closely with nature-based tourism, there has occurred since the early 1990s a substantial expansion of city-based tourism (Rogerson \& Rogerson, 2014, 2017). The growth of urban destinations for leisure and business tourism has been driven in South Africa partly by similar triggers to those in Northern cities around the imperative for economic diversification in the context of high unemployment and escalating urban poverty.

Over the past 15 years the phenomenon of urban tourism has generated a substantial literature in South Africa (Rogerson, 2002, 2011, 2013; Rogerson \& Rogerson, 2014, 2016, 2017; Booyens \& Rogerson, 2015; Greenberg \& Rogerson, 2015; Greenberg \& Rogerson, 2018; Rogerson, 2018a, 2018b). Although certain observers draw attention to the challenges posed by climate change no research so far has been undertaken relating to tourism in the country's major cities. In terms of this knowledge gap the analysis here focuses on the risk perceptions 
of tourism businesses in Johannesburg which is South Africa's major economic hub as well as a leading tourism destination (Rogerson \& Rogerson, 2014, 2015, 2016, 2017). The character of tourism in Johannesburg is distinguished most clearly by the vital role which is assumed by business tourism within the local tourism economy (Rogerson, 2013, 2015; Rogerson \& Rogerson, 2014, 2016, 2017). The analysis unfolds in terms of two further sections of material. In the next section the research is contextualised as part of broader scholarship concerning climate change perceptions and tourism. This sets the stage for investigating the Johannesburg case and the risk perceptions of business tourism stakeholders to the imminent threats of climate change for urban and economic development in South Africa's most important city.

\section{Tourism and climate change perceptions}

In examining tourism and climate change research the importance of undertaking perception studies has long been recognised particularly for informing an understanding of the factors that encourage or constrain policy actions towards climate change mitigation and adaptation (Frondel et al. 2017). The majority of tourism and climate change perception investigations appeared since the early 2000s and given impetus by the World Tourism Organisation's hosting in 2003 of the first conference on climate research and tourism (Becken, 2004: Scott et al., 2012). The main purpose of perception based research is to gain insight into the manner in which tourists and key tourism industry stakeholders view and understand climate change as well as the policy implications of how to better communicate, encourage and manage effective and purposeful climate change related actions (Kallstedt et al., 2008). Perception research studies continue as a critical basis for interpreting adaptation and mitigation responses (or lack thereof) of the tourism sector to climate change.

In a landmark international review Kaján and Saarinen (2013) show the degree to which existing research is both uneven geographically and across different segments of tourism. Existing scholarship is heavily weighted towards interpreting climate change perceptions in the global North and sectorally towards the segments of winter tourism and skiing as well as coastal tourism. For example, Kaján et al. (2015) consider the climate change adaptationbased perceptions of tourism businesses in Finnish Lapland. In Scotland Hopkins and Maclean (2014: 400) research the climate change perceptions of tourism businesses and decision-makers in five main ski areas to disclose the important finding that "waiting for knowledge to increase before taking adaptive action appears to be the most important business strategy". The climate change awareness and adaptation perceptions of downhill ski agents and municipal stakeholders in Germany reveal they repeatedly emphasize uncertainty about relevant scientific facts, a perception which is attributed to mass media reports about "a lack of scientific consensus on climate change issues" (Hoy et al., 2011: 459). In Northern Sweden Brouder and Lundmark (2011) examine the perceptions of winter tourism businesses and conclude venue-based businesses see climate change as a higher priority than activitybased and potentially mobile businesses regardless of location. In Australia Bicknell and McManus (2006: 386) compare perceptions and responses of resort managers and government representatives in the Australian skiing industry and reveal "that the tension between competing firms on the one hand and of industry cooperation on the other strongly influences the types of response that may develop".

The ramifications of climate change for tourism-dependent and vulnerable small island economies are another focus in tourism perceptions research. For example, in Vanuatu Klint 
et al. (2012) explore perception of government climate change adaptation policies by national and local government stakeholders, the tourism industry, development organisations, NGOs and research institutes. In Samoa Wong et al. (2013) investigate the perceptions of key stakeholders involved in the policy, governance and operational aspects of tourism and Parsons et al. (2018) examine the perceptions of local tourism operators regarding climate extremes and adaptive capacity. In an influential contribution Shakeela and Becken (2015: 65) explore how tourism stakeholders in the Maldives perceive climate change risk and conclude "local stakeholders are not immediately concerned, and adaptation measures are woefully inadequate to cope with future climate risks".

Beyond the focus on small islands other coastal destinations have come under academic scrutiny for perception studies. For Australia's Great Barrier Reef Goldberg et al. (2018: 238) find tourism operators "recognise the threat of climate change and strongly support increased action to address it" but as yet businesses are "hesitant to engage their guests about climate change despite acknowledging an interest, expertise and responsibility to do so". Comparing the perceptions of coastal tourism stakeholders at Zandvoort (The Netherlands) and Axarquia (Spain) Gaita and Both (2008: 182-183) disclose among local policy makers and tourism entrepreneurs is a "tendency to delegate the responsibility for defining and taking due actions to the national administrations, justified by the limited availability of resources and expertise at local level". In a survey conducted of tourism academics across nine countries in the EuroMediterranean region focused on beach tourism Valls and Sarda (2009: 49) reveal "uncertainties but no serious worries". Dive operators in the Egyptian Red Sea are the focus of Marshall et al. (2011: 514) who show that with regards to climate change, tourism enterprises "have not yet incorporated information about the climate and environmental interests of their clients into their business thinking". Hoogendoorn et al. (2016: 59) describe the perceptions of tourism accommodation providers and tourists at two South African coastal resorts to reveal "accommodation establishments were predominantly concerned with day-to-day changes in weather".

Rural-focussed climate change perception studies exist both in the context of the global North and South. Stewart et al. (2016) assess the risk perceptions and awareness around climate change related impacts in New Zealand's Westland Tai Poutini National Park for glacierbased tourism. Using semi-structured interviews Roman et al. (2010) explore climate change perceptions of key tourism stakeholders in the Alpine Shire region of Australia concluding that many threats, including climate change, compete for the resources, strategy and direction of local tourism management organisations. In Spain an examination of the perceptions of rural tourism accommodation groups shows that as an outcome of poor planning by tourism stakeholders "the process of diversification that has taken place will not contribute to increasing adaptation's capacity of tourism to climate change or consequently to reducing its level of vulnerability" (Gómez-Martin et al., 2014: 293). Coles et al. (2015: 900) show that "property age does not play a straightforward role in encouraging or hindering efforts among accommodation providers to tackle climate change". For the global South Hambira and Saarinen (2015) determine the climate change perceptions of policy-makers in Botswana and Tervo-Kankare et al. (2018) research climate adaptation perceptions of business entrepreneurs in rural Namibia. The latter study disclosed that even though the majority of entrepreneurs believed climate change would impact the tourism industry, less than half of the respondents considered it might affect their own businesses (Tervo-Kankare et al., 2018). Mushawemhuka et al. (2018) investigate nature tourism operators' perceptions and adaptations to climate change in Hwange National Park, Zimbabwe. 
Overall, across a range of tourism perception studies, it is shown that awareness of climate change is a significant factor for understanding climate change action or inaction among various individuals, groups and organisations. (Kempton, 1991; Bostrom et al., 1994; O'Çonnor et al., 1999; Sheppard, 2005; Moser \& Ekstrom, 2010; Scruggs \& Benegal, 2012; Broomell et al., 2015; Sing et al., 2017). Nevertheless, it is argued that awareness of climate change will not automatically guarantee positive and purposeful climate change related actions (Shakeela \& Becken, 2015). This said, Bostrom et al. (1994: 959) contend that "the provision of information should begin with an "empirical assessment of what people already know along with a scientific determination of what missing information is most critical to their decisions". Nicholson-Cole (2005: 257) asserts the continued relevance of climate change perceptions research as a necessary means to bridge what sociologists style as the 'attitude-behaviour' divide.

A significant new focus in climate change research as a whole surrounds questions about risk perceptions. Climate change is projected to play a role in altering risk patterns on a global scale both by enhancing the impacts and intensity of long established exposure events as well as creating new patterns of risk exposure for individuals, groups and business enterprises that formerly may not have considered themselves at risk (Dessai \& Sims, 2010: Capstick et al., 2015; Helm et al., 2018: Walshe \& Stancioff, 2018). Climate change based risk perceptions are significant because of the manner in which they represent a subjective element of decision-making processes and as such can stall or constrain vital actions needed to reduce risk (Leiserowitz, 2005). A core challenge in dealing with the risks and impacts of climate change relates to the complex channels through which the issue of climate change translates from global phenomenon to being viewed as an important national, regional and ultimately a local issue for concern (Becken et al., 2013; Howe, 2018). Many climate change impacts are embedded slowly in everyday life and therefore often go almost unnoticed (McCright \& Dunlap, 2003; Moser \& Ekstrom, 2010). Weber (2016: 127) maintains that "a major obstacle to motivating action on climate change is the fact that for many people the phenomenon appears not just abstract, but also personally distant in space and in time". Accordingly, Lujala et al. (2015) identify the need to know more about why people have divergent attitudes and perceptions concerning climate change and its possible consequences. Van der Linden (2015: 116) maintains the critical importance of perception research within climate change because "the perception of risk is a mental construct". Risk perception forms a critical component of any conscious and purposeful action as a tangible shift in mental cognition must occur before adaptation actions might be instituted. Indeed, Adger et al. (2009: 346) state that "in situations where no risk is perceived, little if any action to adapt is undertaken". O'Çonnor et al. (1999: 461) draw attention to particular differences between general environmental beliefs on the one hand and risk perceptions on the other; they maintain that risk perceptions "are not a surrogate for general environmental beliefs, but have their own power to account for behavioural intentions". Further, Dong et al. (2018) aver that risk perception of climate change mediates the relationship between information and climate action.

In approaching the issue of climate change and risk perceptions O'Neill and Nicholson-Cole (2009: 265) identify the need for researchers to tread carefully as dramatic representations of climate change impacts can lead to individuals seeking to "distance or disengage" because of feeling helpless or overwhelmed. Arguably, climate change related interactions are complex such that perceptions encompass a wide variety of groups and individuals' cognitive and emotional landscapes. As Wolf and Moser (2011: 6) assert people "are not 'blank slates' receiving information about risks (such as climate change) and interpreting them at face 
value. Rather, such information is always and inevitably filtered through pre-existing cultural worldviews". In many instances, however, several facets of climate change related risks must be regarded as 'slow creeping' because risks are not easily experienced directly and as such tend to not "activate a primal affective/associative risk response" (Van der Linden, 2014: 437). Accordingly, in trying to encourage effective and purposeful climate change related action Howe (2018: 467-468) suggests "the success of these efforts depends heavily on social factors, such as citizen policy preferences and policy support, awareness of appropriate behavioural responses and risk perceptions, among other factors". Further, in attempting interventions Findlater et al. (2018: 178) caution that "the processes of human judgment and decision making involved in harmonizing the management of climate change with weather, climate variability and other 'normal' risks are understudied and therefore poorly understood".

For urban environments whilst a number of investigations exist around climate change related risk (Hunt \& Watkiss, 2007; Mosley, 2014; Hu \& He, 2018; Meerow \& Mitchell, 2017; Torabi et al., 2018) specific questions about climate change and risk perceptions in tourism remain unexplored. This lacuna is unfortunate as the potential benefits of tourism development in cities can be undermined by the impacts of climate change and of the subjective elements attached to the risk perceptions of individuals, groups and organisations that might constrain effective action (Kusakebe et al., 2015). It is against this background of existing scholarship on climate change perceptions and tourism that in the next section the risk perceptions of tourism stakeholders in South Africa's major business tourism destination are the focus of discussion.

\section{The Johannesburg study and findings}

In terms of this research on urban tourism and climate change an overview is given initially of the context of the economy of Johannesburg, its tourism base and climate change assessments. Attention then shifts to the methodology before presentation of research findings concerning risk perceptions and responses of the city's business tourism sector stakeholders.

\subsection{Context}

Johannesburg is South Africa's most economically important city with the finance sector and its allied activities (insurance, accounting and legal services) the leading contributors to Gross Value Added (Rogerson \& Rogerson, 2015; Rogerson, 2018b). Indeed, the city must be recognised as a global service centre in terms of finance, banking and related services (Rogerson \& Rogerson, 2015). Johannesburg's strength in finance and corporate decisionmaking makes it a gateway for international as well as national businesses for the wider economic region of sub-Saharan Africa. The city hosts Africa's largest stock exchange and is the headquarters of the largest share of corporate headquarter offices in South Africa. Until the 1980s much of the core finance and services economy was based geographically in the inner city. However, a flight of capital began and accompanied the emergence and subsequent consolidation of finance capital in decentralized property nodes and most especially in the Northern suburbs area of Sandton which assumed the status of Johannesburg's financial centre (Rogerson, 2018b). The role of the Sandton business district cannot be understated within the city of Johannesburg's broader position as "the preferred choice for business operations both in South Africa and the broader region because of several 
agglomeration factors associated with the city's position as the leading economic hub, financial complex, and core market of Southern Africa" (Rogerson \& Rogerson, 2015: 353).

The global, regional and national significance of Johannesburg in terms of finance, business services and corporate decision-making impacts strongly the growth and character of the city's tourism economy (Rogerson, 2002; Rogerson \& Rogerson, 2017). Since democratic transition in 1994 Johannesburg has been a major beneficiary of the surge in international and domestic tourism that has occurred in South Africa (Rogerson \& Rogerson, 2014). According to IHS Global Insight data between 2001 and 2015 the total number of tourist trips recorded for Johannesburg expanded from 1.9 million to 3.4 million. As a typical multi-purpose urban tourism destination, the largest number of trips are for visiting friends and relatives which is mainly by domestic travellers (Rogerson \& Rogerson, 2016). Leisure travel is of rising significance in the city's tourism economy and since the early 1990s the city has undertaken to expand its offerings in terms of new cultural and heritage attractions as well as the hosting of important sports events. For both local and international tourists shopping is another major attraction in Johannesburg (Rogerson, 2011). Further, for international tourists the role played by Soweto in the anti-apartheid struggle has made it a popular focus for what is termed variously poverty, township or slum tourism (Frenzel, 2016).

By far the most distinguishing feature of Johannesburg's tourism economy, however, is the strength of business tourism which is particularly concentrated in the surrounds of Sandton (Rogerson, 2015; Rogerson \& Rogerson, 2016). The opening of an international standard convention centre in Sandton was a landmark event in consolidating Johannesburg's role as prime destination for international and local conferences. Further reinforcement for the strength of business tourism is the establishment of a cluster of high quality accommodation services sector of four and five star hotels as well as of executive service apartments (Greenberg \& Rogerson, 2015; Rogerson, 2014a). The Sandton node also offers a range of other forms of accommodation hospitality services that might be used by different types of business traveller including all suite hotels, boutique hotels, guest houses, limited service hotels, bed and breakfast establishments and a range of Airbnb options.

As South Africa's most important locus for business tourism as well as the location of the largest cluster of green property developments in the country - including of green hotels the Sandton area of Northern Johannesburg provides an instructive case study in terms of interrogating the risk perceptions and responses of tourism stakeholders concerning climate change (Rogerson, 2014b; Rogerson \& Sims, 2012). Nevertheless, South Africa's national baseline assessments about vulnerability and the impact of climate change on major tourism attractions and activities in the country inevitably focus mainly on nature tourism in the country's protected areas, Cape Town and the Winelands, the Garden Route and the beach attractions of coastal Kwazulu-Natal (Golder Associates, 2012). Only brief mention is given to the potential tourism impacts of climate change in Gauteng province (with Johannesburg its apex) with concerns recorded about electricity supply and access as well as "potential unpleasant weather conditions" (Golder Associates 2012: 17). Johannesburg is already experiencing several negative consequences from climate change most notably warmer than average temperatures (Phalatse \& Mbara, 2009). Climate change predictions point to far reaching impacts for the city. Among the projections of climate models for Johannesburg is for further "significant increases in temperatures over the next four to five decades, with this trend continuing into the subsequent century" (City of Johannesburg, 2014: 2). It is suggested that this warming trend will have a significant impact on average seasonal temperatures with a range of climate model projections pointing to an annualised temperature increase for 
Johannesburg in the order of $2.4^{\circ} \mathrm{C}$ in the near future and up to $4.5^{\circ} \mathrm{C}$ increases in the longer term. In addition, rainfall is expected to increase moderately but significantly in future with increases in the number of rain days and especially of extreme participation events. Overall the climate model projections for Johannesburg suggest that the local climate is likely to become both significantly hotter and more humid (Phalatse, 2011). Indeed, Johannesburg faces a range of climate change impacts around warm spells/heat waves, heavy rainfall and a longer rainy season and the higher frequency of storm events (Phalatse, 2011). These climate futures potentially will impact the city's economy and residents through higher costs of living, threats to water supplies, possible impacts on power supplies and deterioration of air quality (Phalatse, 2011; City of Johannesburg, 2014).

In response to climate change the City of Johannesburg authorities recognised its impacts as "the biggest threat to sustainable development" (Phalatse \& Mbara, 2009: 1). The city undertook a climate change vulnerability study in order to improve its resilience to climate change and to inform Johannesburg's adaptation plan which was to lead to the adoption of a suite of 'no-regrets' adaptation actions. Although the poor were identified as the group most at risk from the ramifications of climate change, policy-makers acknowledged that many sectors in the city must put in place adaptation measures to climate change (Phalatse, 2011). During 2009 the city authorities established a climate change plan with a number of adaptation activities attached to it; in 2012 it developed subsequently a climate change action strategy (City of Johannesburg, 2014). The city is a member of the global C40 cities initiative committed to taking bold actions on tackling climate change, driving urban action that reduces climate risks and thereby charting pathways towards a healthier and sustainable urban environment. Nevertheless, because of institutional changes and budgetary constraints "neither the adaptation plan nor the strategy have ever been implemented" (Hickmann \& Stehle, 2017: 8). Holgate (2007) identifies a group of barriers which impede climate change mitigation implementation in major South African cities (including Johannesburg) amongst which are city internal structures, financing issues and political interventions. As a whole, it is stressed by Hickmann and Stehle (2017: 8) that with its lack of implementation the metropolitan government of Johannesburg still confronts "serious challenges in terms of taking action on climate change", including for the expanding tourism economy.

\subsection{Methods}

In addressing the objective of the research study to analyse the climate change perceptions of key tourism stakeholders in Johannesburg the selected approach was through qualitative interviews. These were conducted with a cross-section of business tourism stakeholders in the Sandton node. All respondents were in managerial positions variously in relation to local area planning, operations of conference centres, or directly responsible for accommodation establishments. Interview respondents were purposively sampled to capture the array of different sizes of accommodation establishment servicing the business traveller in the Sandton area. In total thirty in-depth semi-structured interviews were undertaken; the majority of respondents were drawn from accommodation service establishments. Details of the respondents are given in Table 1. 
Table 1: Details of the 30 respondents interviewed.

\begin{tabular}{|c|c|}
\hline Respondent's role & Business type \\
\hline District manager & Sandton City Improvement District Forum (1) \\
\hline \multirow[t]{21}{*}{ General manager } & Limited service hotel (2) \\
\hline & Large hotel (3) \\
\hline & Large hotel (10) \\
\hline & Large hotel (5) \\
\hline & Large hotel (16) \\
\hline & Limited service hotel (6) \\
\hline & Limited service hotel (29) \\
\hline & All suite hotel $(8)$ \\
\hline & Extended stay hotel (9) \\
\hline & Serviced apartment (12) \\
\hline & Serviced apartment (7) \\
\hline & Serviced apartment (30) \\
\hline & Boutique hotel (11) \\
\hline & Boutique hotel (14) \\
\hline & Guest house (17) \\
\hline & Guest house (18) \\
\hline & Guest house (21) \\
\hline & Guest house (23) \\
\hline & Guest house (27) \\
\hline & Tour operator $(15)$ \\
\hline & Conference centre (13) \\
\hline Head of operations & Conference centre (4) \\
\hline \multirow[t]{7}{*}{ Business owner } & Guest house (19) \\
\hline & Guest house (20) \\
\hline & Guest house (22) \\
\hline & Guest house (26) \\
\hline & Bed and breakfast (24) \\
\hline & Bed and breakfast (25) \\
\hline & Bed and breakfast (28) \\
\hline
\end{tabular}

Length of interviews varied with average interview duration approximately 30 minutes. All interviews were conducted personally at the place of work of respondents, usually an accommodation service establishment. Responses were recorded in notebooks as most interviewees were uncomfortable to have interviews digitally recorded. Interviews were manually coded thematically for analysis in terms of four key overlapping themes. First, the study sought to identify stakeholders' awareness of climate change and sources of knowledge. Second, relates to individual stakeholder's perceptions of the potential risks that climate change might pose to tourism in the Sandton area. Third, the research explored the risk related hazards as perceived by respondents. Finally, the interviews interrogated the extent of actions currently undertaken or planned in relation to climate change adaptation or mitigation. In cases of no actions being undertaken to address climate change the reasons for inaction were probed. Attention now turns to the results relating to these four sets of issues.

\subsection{Results and discussion}

At the outset of analysing risk perceptions of Johannesburg business tourism stakeholders is the question of awareness of climate change. Across all the 30 interviewed respondents listed in Table 1 there was an acknowledgement that tourism stakeholders had heard of the issue and challenges surrounding climate change. Overall, there is disclosed considerable variation in the extent to which tourism stakeholders could articulate the phenomenon. Indeed, the 
inability often to describe issues around climate change points to varying levels of understanding and knowledge about the complexities of climate change. It was disclosed that levels of respondent awareness and knowledge of climate change was associated with the channels through which respondents heard about and interpreted questions around climate change. Of note was variations between respondents associated with larger and corporateowned accommodation establishments on the one hand and smaller, usually independently owned accommodation service providers on the other. For those stakeholders associated with large hotels which are part of international chains or large South African owned hotel groups, respondents highlighted awareness of climate change issues was framed by corporate discussions, internal company reports as well as access to external reports concerning climate change ramifications. By contrast, for smaller establishments, most notably independent guest houses and bed and breakfast providers the major information source for impacting their awareness levels of climate change is that of local media and standard publicly available information sources through television news, local media and radio. Of note is that no mention in the interviews was made of the internet based social media sources such as Facebook as a source of accessing information about climate change. Notwithstanding the limitations attached to access of information to impact knowledge of climate change most Sandton respondents appeared comfortable in the state of their awareness and understanding of climate change issues. Only one exception was noted by the response of one guest house manager who conceded that "climate change is not really a subject that I know very much about" (17).

In seeking to explore risk perceptions the 30 interviewees were asked to reflect on how they considered climate change might impact Johannesburg as a whole and Sandton in particular. In addition, respondents were probed on whether there are any particular weather- or climate related impacts or hazards that would be considered to present a risk to their tourism enterprise. The aggregated findings are presented on Table 2.

Table 2: Perceived risks associated with climate change by Sandon tourism stakeholders.

\begin{tabular}{lll}
\hline Perceived Risk & No. Respondents & \% Respondents \\
\hline Hail & 9 & 30.0 \\
Floods & 3 & 10.0 \\
Lightning & 3 & 10.0 \\
Drought & 1 & 3.3 \\
No impact & 6 & 20.0 \\
Unsure/Don't Know & 8 & 26.7 \\
\hline
\end{tabular}

Note: Some respondents indicated more than one perceived risk.

The results reveal a lack of consensus and understanding by tourism stakeholders of the potential future challenges that confront businesses in Johannesburg as indexed by the findings from climate science research and as acknowledged by city authorities (Phalatse \& Mbara, 2009; Phalatse, 2011; City of Johannesburg, 2014). With the notable exception of the City Improvement Manager for Sandton (1) almost all other interviewees did not perceive climate change as presenting a significant risk either to the Johannesburg tourism economy or specifically to their tourism businesses. Many respondents conceded that climate change might represent a long-term issue which, at the earliest, may impact on them in 10-20 years but not in the immediate short-term (seen as 5 years). The most remarkable finding is, perhaps, that almost half of respondents either perceive no impact risk to their business or are simply unsure/unaware of the threats posed by climate change in Johannesburg. Of the 53 percent of respondents who did offer a response in terms of potential hazards, the greatest concern related to hail with a small number of respondents discussing floods, lightning and 
drought. It was significant that the biggest risk was that in association with violent hailstorms. The respondents did not see even this risk as extreme enough to warrant any kind of systemic response. Indeed, the attitude of respondents is captured by the response of one hotel manager that the worst that could happen was damage to guest cars and that "while it might cause complaints, we aren't liable for any damage to cars so it isn't a major issue... in the long term we might need to budget to have shade netting put up" (29). It should be noted, however, that this lack of concern around a potential weather event is tempered by the fact that most large Sandton hotels already supply outside covered parking as well as undercover parking. Flooding was acknowledged as a risk by three respondents but none of the interviewees could articulate further how flood threats might impact their specific business. One manager of a boutique hotel pointed out that flooding was a highly localized issue which did not impact her establishment which was situated at the top of a slope and despite incidences of heavy rain had no impact on the business. Lightning strikes are a long-term hazard in Johannesburg and a number of respondents noted potential threats for further such strikes. Finally, a small number of respondents did allude to long term threats to water supplies in Johannesburg from climate change. This said, managers added even this was not likely to impact severely their business as they would simply have to ensure that guests could be supplied with bottled drinking water, the costs of which would be passed onto hotel clientele. Of interest was one respondent who discussed the potential impacts of drought conditions in South Africa more broadly as having significant impacts on the costs and availability of food supplies for Johannesburg as well as putting stress on supplies of water which was recognised as essential for the workings of tourism businesses (4).

In examining climate change as a current or future priority for Sandton tourism businesses and the specific actions which businesses undertake for adaptation and mitigation, the results disclose minimal action. Nearly all interviewees noted climate change is simply not a significant business concern at present. As one interviewee suggested: "It's something that we pay lip service to from time to time" (3). A key consideration in understanding why climate change related potential impacts are not generally considered a high priority by Sandton tourism businesses is the way Johannesburg is currently perceived by tourism stakeholders as facing lesser challenges (and potential impacts) than other South African cities and regions. One respondent spoke as follows: "I don't see it (climate change) as a major issue. We are way more temperate weather wise than the rest of the country" (12). Another interviewee stated that unlike many other parts of the country that might face increasing climate change related issues "We also have infrastructure" (5). This point was reinforced further by citing that Sandton represents not just Johannesburg's financial hub but the financial heart of South Africa and recollecting that at the height of South Africa's electricity crisis in 2008 the city's former mayor promised "Sandton will always have power, even if it means setting up generators to exclusively supply electricity to it" (5). The particular nature of the Sandton tourism economy was observed by another respondent as minimizing the threats of climate change: "As long as Sandton stays where it is, we'll always have business here. It's the companies located in Sandton that influence tourism here" (30). Likewise, other interviewees considered the nature of business tourism markedly different to leisure-based tourism: “We are not a resort. Weather isn't a big issue, we are a corporate hotel" (16) and that regardless of weather conditions "People will still have meetings" (13). Only one interviewee appeared concerned seriously about future climate change impacts of extreme weather events on their business in stating that if an extreme event ever took place in Sandton "Are we prepared? I'd say we aren't, but then we've never been tested" (1). This comment aside, for the rest of the interviewed tourism stakeholders minimal concerned was expressed about potential risks and responses in terms of mitigation or adaptation. 
Finally, some discussion is in order about the 'greening' of Sandton tourism enterprises an issue identified in previous research on the environmental practices of local hotels (Ismail \& Rogerson, 2016; Rogerson \& Sims, 2012). Across the different kinds of accommodation establishments that were interviewed in this research widespread acknowledgement exists of the importance and need for businesses to prioritise green or environmentally friendly practices. In common with the findings of Rogerson and Sims (2012), however, it is economic motivations in terms of the significant cost savings associated with reductions in energy use, and the benefits associated with being resource efficient that is the key driver as opposed to issues of vulnerability to the risks or potential impacts associated with climate change. Indeed, because of the financial incentives attached to energy and resource efficient reductions several respondents highlighted "greening is a big issue for business" (5) and more specifically "electricity and water shortages are a big issue" (16). The most common barrier for going 'green' relates to costs associated with new infrastructure or technologies. One hotel manager stressed the challenge or 'balancing act' with going green and "finding $a$ balance between what is commercially viable versus responsible and environmentally viable is tough" (10). Another respondent noted: "It (greening) is a combo of environmental responsibility as well as having a bottom line" (14). In understanding the extent to which environmentally friendly or 'green' based actions are prioritised and undertaken by tourism businesses, a distinction emerges between operational practices that attempt to encourage more environmentally responsible behaviour by staff and guests, and infrastructure-based investment which seeks to improve the physical capacity of tourism business towards greater resource efficiency. Most Sandton respondents prefer the use of operational actions for 'greening' over efficient capacity building because of cost considerations. One typical response is "the current cost of construction makes things very difficult" (9). Furthermore, construction work for greening impacts business operations; it was observed tourism businesses "can't have heavy construction going on while still you have guests" (30). Furthermore, for many smaller accommodation businesses, the costs associated with extensive green infrastructure development or for retrofitting existing facilities is sometimes difficult to justify. As one respondent recalled: "We looked into having solar panels installed because of regular load shedding and it would have cost over R2.5 million upfront" (7). Lack of financing for greening was raised as a barrier: "Banks don't really finance things like solar, so it becomes impossible for small business like mine to even think about it" described the owner of a local guest house (27). This viewpoint was confirmed by the manager of a local independently owned hotel who conceded the challenge of old or "aging infrastructure", stating that the establishment's "infrastructure was never designed to be green" (5) and "it would actually be easier to knock down the entire hotel and start from scratch rather than trying to add on" (5).

Overall, because of the financial challenges facing long-established accommodation businesses around implementing new greening infrastructure the most common responses are small-scale and non-invasive interventions such as the widespread introduction of power efficient lights or motion sensors. In newer Sandton hotel developments, many associated with South Africa's hosting of the 2010 FIFA World Cup of soccer, greater investments were made to 'green' technologies with infrastructure such as grey water recycling systems described as "a basic requirement for new hotels" (3). Most respondents did not view the introduction of improved greening or environmental practices as translating into enhanced competitive advantage. As discussed also by Ismail and Rogerson (2016) and Rogerson and Sims (2012) the majority of Sandton tourism enterprises respondents consider that South Africa and local consumers "are still behind Europe" (19) in terms of environmental awareness and reiterated that environmental consciousness was inseparable from economic 
considerations. One interviewee reflected that "We've found that encouraging simple things like asking guests to not change their towels everyday can add up" (3). Likewise, basic greening or climate change mitigation measures, such as training staff to be greener and actively encouraging guests to be more environmentally conscious in their use of power or water, can have significant financial returns. By contrast, the unknown risks associated with climate change and the pursuit of other climate change adaptation measures are far less inviting at present for Sandton tourism businesses. One respondent remarked: "At this place we don't have any huge strategy plans in place because we don't see it (climate change) as a threat" (8). Rather, "we mostly stick to small scale strategies like recycling" (8). In seeking to understand what might lead to future climate change based adaptive action by the tourism industry in Sandton two types of responses emerge. First, is that core responsibility for active climate change related action was seen to rest with national and local government and it was viewed government should take the lead in driving climate change education, policy, incentives and enforcement measures. This was made clear by one respondent: "When government tells us what they want us to do and makes it mandatory for us to keep doing business, then we'll follow" (25). A second response was that the industry would take concrete action towards adaptation only "if and when climate change became an issue" (1). Likewise, another interviewee stated "we haven't really explored the option yet" but was certain that the industry would adapt when such action is needed (9). Overall, these responses reaffirm the limited current awareness levels and risk perceptions of Sandton tourism businesses towards climate change issues.

In unpacking individual stakeholder views, significant variations are apparent between stakeholder perceptions of climate change mitigation and adaptation. It is evident that whereas most Sandton stakeholders interviewed do not view climate change related risks, impacts, or hazards as of major contemporary concern, mitigation actions are perceived positively by all interviewees. In particular, with respect to energy saving measures all stakeholders claimed to make extensive use of electricity saving devices. One interviewee responded that "everyone has to start greening" (21). The greater acceptance of mitigation actions is underpinning by two factors. First, that by acting environmentally conscious and undertaking certain mitigation-based actions, business operating costs are reduced: in the words of one interviewee, being green is ultimately "good for your bottom line" (11). Second, the impact of legislation on businesses undertaking mitigation based or "environmentally friendly' actions must be recognised. Managers of new hotels stressed that planning requirements for permits for new constructions require the incorporation of greywater recycling systems and power efficient layouts. In the case of accommodation providers linked to international hospitality brands (or under management by such groups), corporate environmental policies demand the introduction of such greening practices. A long term challenge for further deepening of climate change mitigation practices relates to guest attitudes. It was highlighted that most South African guests are yet to embrace environmentally responsible behaviour. As one respondent stated: "Some guests appear to assume that because they have paid for their accommodation that they are entitled to use as much water as they like, waste power, and demand fresh towels every day even though they would never behave like that at home. They somehow feel entitled to" (24). By contrast to mitigation-based actions, Sandton tourism stakeholders appear only minimally concerned with climate change related adaptive actions. The consensus appears to be a wait and see attitude towards climate change before taking any actions. One respondent argued we "would need to see it impact on us first" (29). Another noted revealingly that "Adaptation starts when there is a huge need because of financial loss" (17). 


\section{Conclusion}

With more than half the world's population now resident in cities it is urgent that the agenda of climate change research be extended specifically to consider urban environments (Hunt \& Watkiss, 2007). Although the growth of research is occurring across several urban impact issues it is argued here that an important investigatory void surrounds climate change and city tourism. The importance of this topic for researchers is underscored by the significance of tourism for urban development both in the contexts of Northern cities as well as the global South. Accordingly, this study adds to a mounting body of academic writings which examine both city-scale issues and climate change as well as specifically to considerations around tourism and climate change. The setting of Johannesburg - a city that in recent years has experienced considerable warming as well as changing rainfall patterns - makes the findings of this study particularly relevant to debates about Southern cities.

The overall findings point to a major disconnect between the climate change threats as openly recognised by Johannesburg city authorities and the risk perceptions as expressed by Sandton tourism stakeholders. The climate change models for Johannesburg point to potentially major changes in the city's future climate regime. As conceded by city officials the models suggest the city's temperatures may rise by around $2.3^{\circ} \mathrm{C}$ in the near future $(2056-2065)$ and around $4.4^{\circ} \mathrm{C}$ in the far future. In addition, there is a substantial risk that Johannesburg will experience an increase in rainfall patterns characterised by a higher frequency of storm events and a longer rain season (Phalatse, 2011; City of Johannesburg, 2014). It is apparent that Sandton tourism businesses presently are woefully unprepared for the challenges from climate change. Risk perceptions about the potential projected consequences of climate change for tourism businesses are low and have not catalysed any significant systemic responses beyond small-scale greening initiatives which are driven more by economic cost saving reasons rather than as responses to climate change. In several respects the central findings from this investigation confirm those of broader research studies concerning tourism and climate change adaptation in South Africa. It is concluded in national baseline assessments variously that "climate change issues are not discussed at the various levels within the sector", that in the context of a recent downturn in the tourism economy "the controversies regarding climate change has also led to a certain resistance to discussion and response initiatives within the sector" (Golder Associates, 2012: 20). Overall, the consensus among tourism industry stakeholders in South Africa is that climate change and associated sustainability initiatives are viewed "as something of a "nice to have' rather than a necessity" (Golder Associates, 2012: 20). In final analysis these results are indicative that climate change represents a sustainability challenge that must be regarded, following Dymitrow and Halfacree (2018: 7), as illustrative of the 'wicked problems' or global issues that are "multidimensional, hard to pin down and consequently extremely challenging to solve".

Wayde R. Pandy, School of Tourism \& Hospitality, University of Johannesburg, South Africa (Wayde360@gmail.com)

Christian M. Rogerson, School of Tourism \& Hospitality, University of Johannesburg, South Africa(Crogerson@uj.ac.za) 


\section{Acknowledgements}

Thanks to two journal referees for comments on an earlier version and to Arabella Rogerson for substantial editorial assistance.

\section{References}

Adger, W. N., Dessai, S., Goulden, M., Hulme, M., Lorenzoni, I., Nelson, D. R., Naess, L. O., Wolf, J. \& Wreford, A. (2009) Are there social limits to adaptation to climate change?. Climatic Change, 93(3-4), pp. 335-354. DOI: $10.1007 / \mathrm{s} 10584-008-9520-\mathrm{z}$

Arit, W. G. (2009) Climate change and urban tourism in China. Paper presented at China International Leisure Forum, Zhejiang University, Hangzhou, China. Typescript.

Becken, S. (2004) How tourists and tourism experts perceive climate change and carbon-offsetting schemes. Journal of Sustainable Tourism, 12(4), pp. 332-345. DOI: 10.1080/09669580408667241

Becken, S. (2013) A review of tourism and climate change as an evolving knowledge domain. Tourism Management Perspectives, 6, pp. 53-62. DOI: 10.1016/j.tmp.2012.11.006

Becken, S., Lama, A. K. \& Espiner, S. (2013) The cultural context of climate change impacts: Perceptions among community members in the Annapurna Conservation Area, Nepal. Environmental Development, 8, pp. 22-37. DOI: 10.1016/j.envdev.2013.05.007

Bicknell, S. \& McManus, P. (2006) The canary in the coalmine: Australian ski resorts and their response to climate change. Geographical Research, 44(4), pp. 386-400. DOI: 10.1111/j.1745-5871.2006.00409.x

Booyens, I. \& Rogerson, C. M. (2015) Creative tourism in Cape Town: An innovation perspective. Urban Forum, 26(4), pp. 405-424. DOI: 10.1007/s12132-015-9251-y

Bostrom, A., Morgan, M. G., Fischhoff, B. \& Read, D. (1994) What do people know about global climate change?. Mental models. Risk Analysis, 14(6), pp. 959-970. DOI: 10.1111/j.1539-6924.1994.tb00065.x

Broomell, S. B., Budescu, D. V. \& Por, H. H. (2015) Personal experience with climate change predicts intentions to act. Global Environmental Change, 32, pp. 67-73. DOI: 10.1016/j.gloenvcha.2015.03.001

Brouder, P. \& Lundmark, L. (2011) Climate change in Northern Sweden: Intra-regional perceptions of vulnerability among winter-oriented tourism businesses. Journal of Sustainable Tourism, 19(8), pp. 919 933. DOI: $10.1080 / 09669582.2011 .573073$

Capstick, S., Whitmarsh, L., Poortinga, W., Pidgeon, N. \& Upham, P. (2015) International trends in public perceptions of climate change over the past quarter century. Wiley Interdisciplinary Reviews: Climate Change, 6(1), pp. 35-61. DOI: 10.1002/wcc.321

Carmin, J., Anguelovski, I. \& Roberts, D. (2012) Urban climate adaptation in the global south: Planning in an emerging policy domain. Journal of Planning Education and Research, 32(1), pp. 18-32. DOI: $10.1177 / 0739456 \mathrm{X} 11430951$

City of Johannesburg (2014) Climate change mitigation: adaptation and resilience in the city. Presentation at the C40 Cities Climate Leadership Summit, 4-6 February, Johannesburg.

Coles, T., Dinan, C. \& Warren, N. (2015) Climate change mitigation and the age of tourism accommodation buildings: a UK perspective. Journal of Sustainable Tourism, 23(6), pp. 900-921. DOI: $10.1080 / 09669582.2015 .1027213$

Cudny, W. (2011) Film festivals in Lodz as a main component of urban cultural tourism. Bulletin of Geography: Socio-Economic Series, 15, pp. 131-141. DOI: 10.2478/v10089-011-0009-6

Department of Environmental Affairs (2018) Climate change bill 2018. Government Gazette, 636, No. 41689. Pretoria, Government Printer.

Department of Tourism (2012) Final national tourism and climate change response programme and action plan. Pretoria.

Dessai, S. \& Sims, C. (2010) Public perception of drought and climate change in southeast England. Environmental Hazards, 9(4), pp. 340-357. DOI: 10.3763/ehaz.2010.0037

Dong, Y., Hu, S. \& Zhu, J. (2018) From source credibility to risk perception: How and when climate information matters to action. Resources, Conservation and Recycling, 136, pp. 410-417. DOI: 10.1016/j.resconrec.2018.05.012

Dymitrow, M. \& Halfacree, K. (2018) Sustainably - differently. Bulletin of Geography: Socio-Economic Series, 40, pp. 7-16.

Eliasson, I. \& Thorsson, S. (2018) Urban tourism and climate change. Available at: https://gvc.gu.se/english/staff/thorsson-sofia/current-projects/urban-tourism-and-climate-change (accessed 31 May 2018).

Fang, Y., Yin, J. \& Wu, B. (2018) Climate change and tourism: A scientometric analysis using CiteSpace. Journal of Sustainable Tourism, 26(1), pp. 108-126. DOI: 10.1080/09669582.2017.1329310 
Findlater, K. M., Donner, S. D., Satterfield, T. \& Kandlikar, M. (2018) Integration anxiety: the cognitive isolation of climate change. Global Environmental Change, 50, pp. 178-189.

DOI: $10.1016 /$ j.gloenvcha.2018.02.010

Frenzel, F. (2016). Slumming it: The tourist valorization of urban poverty. London, Zed.

Frondel, M., Simora, M. \& Sommer, S. (2017) Risk perception of climate change: Empirical evidence for Germany. Ecological Economics, 137, pp. 173-183. DOI: 10.1016/j.ecolecon.2017.02.019

Gaita, R. \& Both, M. (2008) Climate change and local awareness: a comparative study on tourism stakeholders in Zandvoort (NL) and Costa del Sol (ES). Sustainable Tourism III, 3, pp. 111175. DOI: $10.2495 / \mathrm{ST} 080181$

Goldberg, J., Birtles, A., Marshall, N., Curnock, M., Case, P. \& Beeden, R. (2018) The role of Great Barrier Reef tourism operators in addressing climate change through strategic communication and direct action. Journal of Sustainable Tourism, 26(2), pp. 238-256. DOI: 10.1080/09669582.2017.1343339

Golder Associates (2012) Vulnerability and Impact of Climate change on major tourism attractions and activities: Baseline assessment. Report submitted to Deutsche Gesellschaft fur Internationale Zusammenarbeit (GIZ), South Africa Office, Pretoria.

Gómez-Martín, M. B., Armesto-López, X. A., Cors-Iglesias, M. \& Muñoz-Negrete, J. (2014) Adaptation strategies to climate change in the tourist sector: The case of coastal tourism in Spain. Turizam, 62(3), pp. 293-308.

Greenberg, D. \& Rogerson, J. M. (2015) The serviced apartment industry of South Africa: A new phenomenon in urban tourism. Urban Forum, 26(4), pp. 467-482. DOI: 10.1007/s12132-015-9266-4

Greenberg, D. \& Rogerson, J. M. (2018) Accommodating business travellers: The organisation and spaces of serviced apartments in Cape Town, South Africa. Bulletin of Geography: Socio-Economic Series, 42, pp. 83-97. DOI: $10.2478 /$ bog-2018-0032

Hall, C. M. (2008) Tourism and climate change: Knowledge gaps and issues. Tourism Recreation Research, 33(3), pp. 339-350. DOI: 10.1080/02508281.2008.11081557

Hall, C. M. (2018) Climate change and its impacts on coastal tourism: Regional assessments, gaps and issues. In: Jones, A. L. \& Phillips, M. (eds.) Global climate change and coastal tourism: Recognizing problems, Managing solutions and future expectations, pp. 27-48, Wallingford, CABI. DOI: 10.1079/9781780648439.0048

Hambira, W. L. \& Saarinen, J. (2015) Policy-makers' perceptions of the tourism-climate change nexus: Policy needs and constraints in Botswana. Development Southern Africa, 32(3), pp. 350-362. DOI: 10.1080/0376835X.2015.1010716

Helm, S. V., Pollitt, A., Barnett, M. A., Curran, M. A. \& Craig, Z. R. (2018) Differentiating environmental concern in the context of psychological adaption to climate change. Global Environmental Change, 48, pp.158-167. DOI: 10.1016/j.gloenvcha.2017.11.012

Hickmann, T. \& Stehle, F. (2017) Urban climate governance experiments in South Africa: Insights from Johannesburg, Cape Town and Durban. Paper presented at ISA Annual Conference, Baltimore, USA, 22-25 February.

Holgate, C. (2007) Factors and actors in climate change mitigation: A tale of two South African cities. Local Environment, 12(5), pp. 471-484. DOI: 10.1080/13549830701656994

Hoogendoorn, G., Grant, B. \& Fitchett, J. M. (2016) Disjunct perceptions? Climate change threats in two-low lying South African coastal towns. Bulletin of Geography: Socio-Economic Series, 31, pp. 59-71. DOI: $10.1515 /$ bog-2016-0005

Hopkins, D. \& Maclean, K. (2014) Climate change perceptions and responses in Scotland's ski industry. Tourism Geographies, 16(3), pp. 400-414. DOI: 10.1080/14616688.2013.823457

Howe, P. D. (2018) Perceptions of seasonal weather are linked to beliefs about global climate change: Evidence from Norway. Climatic Change, 148(4), pp. 467-480. DOI: 10.1007/s10584-018-2210-6

Hoy, A., Hänsel, S. \& Matschullat, J. (2011) How can winter tourism adapt to climate change in Saxony's mountains?. Regional Environmental Change, 11(3), pp. 459-469. DOI: 10.1007/s10113-010-0155-z

$\mathrm{Hu}$, Q. \& He, X. (2018) An integrated approach to evaluate urban adaptive capacity to climate change. Sustainability, 10(4), pp. 1272. DOI: 10.3390/su10041272

Hunt, A. \& Watkiss, P. (2007) Literature review on climate change impacts on urban city centres: Initial findings. Document ENV/EPOC/GSP (2007)10/FINAL. Paris, OECD.

Ismail, S. \& Rogerson, J. M. (2016) Retrofitting hotels: evidence from the Protea Hospitality Group of hotels within Gauteng, South Africa. African Journal of Hospitality, Tourism and Leisure, 5(3), pp. 1-14.

Jones, S. (2017) Cities responding to climate change: Copenhagen, Stockholm and Tokyo. Cham, Palgrave Macmillan.

Judd, J. R. (ed.) (2015) The infrastructure of play: Building the tourist city. London, Routledge.

Kadar, B. (2013) Differences in the spatial patterns of urban tourism in Vienna and Prague. Urbani izziv, 24(2), pp. 96-111. DOI: 10.5379/urbani-izziv-en-2013-24-02-002 
Kaján, E. \& Saarinen, J. (2013) Tourism, climate change and adaptation: A review. Current Issues in Tourism, 16(2), pp. 167-195. DOI: 10.1080/13683500.2013.774323

Kaján, E., Tervo-Kankare, K. \& Saarinen, J. (2015) Cost of adaptation to climate change in tourism: Methodological challenges and trends for future studies in adaptation. Scandinavian Journal of Hospitality and Tourism, 15(3), pp. 311-317. DOI: 10.1080/15022250.2014.970665

Kellstedt, P. M., Zahran, S. \& Vedlitz, A. (2008) Personal efficacy, the information environment, and attitudes toward global warming and climate change in the United States. Risk Analysis: An International Journal, 28(1), pp. 113-126. DOI: 10.1111/j.1539-6924.2008.01010.x

Kempton, W. (1991) Lay perspectives on global climate change. Global Environmental Change, 1(3), pp. 183208. DOI: 10.1016/0959-3780(91)90042-R

Klint, L. M., Wong, E., Jiang, M., Delacy, T., Harrison, D. \& Dominey-Howes, D. (2012) Climate change adaptation in the Pacific Island tourism sector: Analysing the policy environment in Vanuatu. Current Issues in Tourism, 15(3), pp. 247-274. DOI: 10.1080/13683500.2011.608841

Law, C. M. (1992) Urban tourism and its contribution to economic regeneration. Urban Studies, 29, pp. 599618. DOI: $10.1080 / 00420989220080581$

Law, C. M. (1993) Urban tourism: Attracting visitors to large cities. London: Mansell.

Leiserowitz, A. A. (2005) American risk perceptions: Is climate change dangerous?. Risk Analysis: An International Journal, 25(6), pp. 1433-1442. DOI: 10.1111/j.1540-6261.2005.00690.x

Lujala, P., Lein, H. \& Rød, J. K. (2015). Climate change, natural hazards, and risk perception: the role of proximity and personal experience. Local Environment, 20(4), pp. 489-509. DOI: $10.1080 / 13549839.2014 .887666$

Marshall, N.A., Marshall, P.A., Abdulla, A., Rouphael, T. \& Ali, A. (2011) Preparing for climate change: recognising its early impacts through the perceptions of dive tourists and dive operators in the Egyptian Red Sea. Current Issues in Tourism, 14(6), pp. 507-518. DOI: 10.1080/13683500.2010.512075

McCright, A. M. \& Dunlap, R. E. (2003) Defeating Kyoto: The conservative movement's impact on US climate change policy. Social Problems, 50(3), pp. 348-373. DOI: 10.1525/sp.2003.50.3.348

Moser, S. C. \& Ekstrom, J. A. (2010) A framework to diagnose barriers to climate change adaptation. Proceedings of the National Academy of Sciences, pp. 201007887, DOI: 10.1073/pnas.1007887107

Mushawemhuka, W., Rogerson, J. M. \& Saarinen, J. (2018) Nature-based tourism operators' perceptions and adaptation to climate change in Hwange National Park, Zimbabwe. Bulletin of Geography: SocioEconomic Series, 42, pp. 115-127. DOI: 10.2478/bog-2018-0034

Nicholson-Cole, S. A. (2005) Representing climate change futures: a critique on the use of images for visual communication. Computers, Environment and Urban Systems, 29(3), pp. 255-273. DOI: 10.1016/j.compenvurbsys.2004.05.002

O’Connor, R. E., Bard, R. J. \& Fisher, A. (1999). Risk perceptions, general environmental beliefs, and willingness to address climate change. Risk Analysis, 19(3), pp. 461-471. DOI: 10.1111/j.15396924.1999.tb00421.x

O'Neill, S. \& Nicholson-Cole, S. (2009) "Fear won't do it" promoting positive engagement with climate change through visual and iconic representations. Science Communication, 30(3), pp. 355-379. DOI: $10.1177 / 1075547008329201$

Pandy, W. R. (2017) Tourism enterprises and climate change: some research imperatives. African Journal of Hospitality, Tourism and Leisure, 6(4), pp. 1-18.

Pandy, W. R. \& Rogerson, C. M. (2018) Tourism and climate change: stakeholder perceptions of at risk tourism segments in South Africa. Euroeconomica, 37, pp. 98-112.

Pang, S. F. H., McKercher, B. \& Prideaux, B. (2013) Climate change and tourism: An overview. Asia Pacific Journal of Tourism Research, 18(1-2), pp. 1-20. DOI: 10.1080/10941665.2012.688509

Parsons, M., Brown, C., Nalau, J. \& Fisher, K. (2018) Assessing adaptive capacity and adaptation: Insights from Samoan tourism operators. Climate and Development, 10(7), pp. 644-663. DOI: $10.1080 / 17565529.2017 .1410082$

Pasquinelli, C. (2015) Urban Tourism (s): Is there a case for a paradigm shift?. Cities Research Unit Working Papers No. 14. L' Aquila, Gran Sasso Science Institute.

Phalatse, L. (2011) Vulnerability assessment and adaptation planning for the City of Johannesburg. Paper presented at the Resilient Cities 2011 Congress. Bonn, Germany.

Phalatse, L. \& Mbara, G. (2009) Impacts of climate change and vulnerable communities at the City of Johannesburg. Paper presented at the Fifth Urban Research Symposium, Johannesburg.

Reckien, D., Creutzig, F., Fernandez, B., Lwasa, S., Tovar-Restrepo, M., McEvoy, D. \& Satterthwaite, D. (2017) Climate change, equity and the Sustainable Development Goals: An urban perspective. Environment and Urbanization, 29(1), pp. 159-182. DOI: 10.1177/0956247816677778

Rogerson, C. M. (2002) Urban tourism in the developing world: The case of Johannesburg. Development Southern Africa, 19(1), pp. 169-190. DOI: 10.1080/03768350220123927 
Rogerson, C. M. (2011) Urban tourism and regional tourists: Shopping in Johannesburg, South Africa. Tijdschrift voor Economische en Sociale Geografie, 102(3), pp. 316-330. DOI: 10.1111/j.1467-9663.2011.00666.x

Rogerson, C. M. (2013) Urban tourism, economic regeneration and inclusion: Evidence from South Africa. Local Economy, 28(2), pp. 186-200. DOI: 10.1177/0269094212463789

Rogerson, C. M. (2014) Reframing place-based economic development in South Africa: The example of local economic development. Bulletin of Geography: Socio-Economic Series, 24, pp. 203-218. DOI: 10.2478/bog2014-0023

Rogerson, C. M. (2015) The uneven geography of business tourism in South Africa. South African Geographical Journal, 97(2), pp. 183-202. DOI: 10.1080/03736245.2015.1028984

Rogerson, C. M. (2016) Climate change, tourism and local economic development in South Africa. Local Economy, 31(1-2), pp. 322-331. DOI: 10.1177/0269094215624354

Rogerson, C. M. (2018a) Informal sector city tourism: Cross border shoppers in Johannesburg. GeoJournal of Tourism and Geosites, 22(2), pp. 372-387.

Rogerson, C. M. (2018b) Urban tourism, aerotropolis and local economic development planning: O. R. Tambo International Airport, Ekurhuleni, South Africa. Miscellanea Geographica-Regional Studies on Development, 22(3), pp. 123-129.

Rogerson, C. M. (2018c) Unpacking the changing economic geography of Gauteng's tertiary sector. In: Cheruiyot, K. (ed.) The Changing Space Economy of City-Regions, pp. 157-184. Cham, Springer. DOI: 10.1007/978-3319-67483-4_6

Rogerson, C. M. \& Rogerson, J. M. (2014) Urban tourism destinations in South Africa: Divergent trajectories 20012012. Urbani izziv, 25(Supplement), pp. S189-S203. DOI: 10.5379/urbani-izziv-en-2014-25-supplement014

Rogerson, C. M. \& Rogerson, J. M. (2015) Johannesburg 2030: The economic contours of a 'linking global city'. American Behavioural Scientist, 59, pp. 347-368. DOI: 10.1177/0002764214550303

Rogerson, C. M. \& Rogerson, J. M. (2016) Intra-urban spatial differentiation of tourism: Evidence from Johannesburg, South Africa. Urbani izziv, 27(2), pp. 125-137. DOI: 10.5379/urbani-izziv-en-2016-27-02004

Rogerson, C. M. \& Rogerson, J. M. (2017) City tourism in South Africa: Diversity and change. Tourism Review International, 21(2), pp. 193-211. DOI: 10.3727/154427217X14984977561745

Rogerson, J. M. (2014a) Hotel location in Africa's world class city: The case of Johannesburg, South Africa. Bulletin of Geography: Socio-Economic Series, 25, pp. 181-196. DOI: 10.2478/bog-2014-0038

Rogerson, J. M. (2014b) Green commercial property developments in urban South Africa: emerging trends, emerging geographies. Bulletin of Geography: Socio-Economic Series, 26, pp. 233-246. DOI: $10.2478 /$ bog-2014-0056

Rogerson, J. M. \& Sims, S. (2012) The greening of urban hotels in South Africa: Evidence from Gauteng. Urban Forum, 23(3), pp. 391-407. DOI: 10.1007/s12132-012-9160-2

Roman, C. E., Lynch, A. H. \& Dominey-Howes, D. (2010) Uncovering the essence of the climate change adaptation problem - A case study of the tourism sector at Alpine Shire, Victoria, Australia. Tourism and Hospitality Planning \& Development, 7(3), pp. 237-252. DOI: 10.1080/1479053X.2010.503049

Satterthwaite, D., Huq, S., Reid, H., Pelling, M. \& Lankao, P. R. (2007) adapting to climate change in urban areas: The possibilities and constraints in low-and middle-income nations. London, International Institute of Environment and Development.

Scott, D., Hall, C. M. \& Gössling, S. (2012) Tourism and climate change: Impacts, adaptation and mitigation. London, Routledge. DOI: 10.4324/9780203127490

Scruggs, L. \& Benegal, S. (2012) Declining public concern about climate change: Can we blame the great recession?. Global Environmental Change, 22(2), pp. 505-515. DOI: 10.1016/j.gloenvcha.2012.01.002

Shakeela, A. \& Becken, S. (2015) Understanding tourism leaders' perceptions of risks from climate change: An assessment of policy-making processes in the Maldives using the social amplification of risk framework (SARF). Journal of Sustainable Tourism, 23(1), pp. 65-84. DOI: 10.1080/09669582.2014.918135

Sheppard, S. R. (2005) Landscape visualisation and climate change: The potential for influencing perceptions and behaviour. Environmental Science \& Policy, 8(6), pp. 637-654. DOI: 10.1016/j.envsci.2005.08.002

Singh, A. S., Zwickle, A., Bruskotter, J. T. \& Wilson, R. (2017) The perceived psychological distance of climate change impacts and its influence on support for adaptation policy. Environmental Science \& Policy, 73, pp. 93-99. DOI: 10.1016/j.envsci.2017.04.011

Stewart, E. J., Wilson, J., Espiner, S., Purdie, H., Lemieux, C. \& Dawson, J. (2016) Implications of climate change for glacier tourism. Tourism Geographies, 18(4), pp. 377-398.

DOI: 10.1080/14616688.2016.1198416

Tervo-Kankare, K., Saarinen, J., Kimaro, M. E. \& Moswete, N. N. (2018) Nature-based tourism operators' responses to changing environment and climate in Uis, Namibia. African Geographical Review, 37(3), pp. 273-282. 
Urquhart, P., Lotz-Sisitka, H., Kruger, B. \& Naude, J. (2014) SARUA Climate Change Counts Mapping Study Volume 1 Knowledge Co-Production Framework. Johannesburg, Southern African Regional Universities Association (SARUA).

Valls, J. F. \& Sarda, R. (2009) Tourism expert perceptions for evaluating climate change impacts on the EuroMediterranean tourism industry. Tourism Review, 64(2), pp. 41-51. DOI: 10.1108/16605370910963518

Van der Linden, S. (2014) On the relationship between personal experience, affect and risk perception: The case of climate change. European Journal of Social Psychology, 44(5), pp. 430-440. DOI: 10.1002/ejsp.2008

Van der Linden, S. (2015) The social-psychological determinants of climate change risk perceptions: Towards a comprehensive model, Journal of Environmental Psychology, 41, pp. 112-124. DOI: 10.1016/j.jenvp.2014.11.012

Walshe, R. A. \& Stancioff, C. E. (2018) Small island perspectives on climate change. Island Studies Journal, 13(1), pp. 13-24. DOI: $10.24043 /$ isj.56

Weber, E. U. (2016) What shapes perceptions of climate change?: New research since 2010. Wiley Interdisciplinary Reviews: Climate Change, 7(1), pp. 125-134. DOI: 10.1002/wcc.377

Wolf, J. \& Moser, S. C. (2011) Individual understandings, perceptions, and engagement with climate change: insights from in-depth studies across the world. Wiley Interdisciplinary Reviews: Climate Change, 2(4), pp. 547-569. DOI: $10.1002 /$ wcc. 120

Wong, E., Jiang, M., Klint, L., DeLacy, T., Harrison, D. \& Dominey-Howes, D. (2013) Policy environment for the tourism sector's adaptation to climate change in the South Pacific-The case of Samoa. Asia Pacific Journal of Tourism Research, 18(1-2), pp. 52-71. DOI: 10.1080/10941665.2012.688511 